\title{
Biological data on Triops cancriformis mauritanicus (Ghigi,1921) and Cyzicus grubei (Simon, 1886) - crustacea, branchiopoda - in SW Portugal temporary ponds
}

\author{
M. Machado ${ }^{1}$, M. Cristo ${ }^{1}$, J. Reis ${ }^{1} \&$ L. Cancela da Fonseca ${ }^{2}$ \\ 1. CCMAR and FCMA, Universidade do Algarve, Campus de Gambelas, P-8000 Faro. 2. IMAR and FCMA, \\ Universidade do Algarve, Campus de Gambelas, P-8000 Faro
}

\begin{abstract}
The lack of information about Notostraca and Spinicaudata in general, and particularly about these taxa in Portugal, can be due to the fact that they are typical of temporary ponds. As most of the species only occur in this kind of habitats, which are highly vulnerable to human action, the study of these systems is of great importance in order to define strategies for their conservation. In April 1996, Triops cancriformis mauritanicus - Branchiopoda, Notostraca - was found in six lagoons from the Vila do Bispo area and in two of those was also found Cyzicus grubei (Simon) - Branchiopoda, Spinicaudata - a species considered endemic to the Iberian Peninsula. In spite of being previously cited as part of the Portuguese fauna (in 1944 and 1951) they were only recently reported in Southwest Portugal (Machado et al., 1999) and there are no other recent records in Portugal. The dimensions of T. c. mauritanicus (maximum standard length $=68.3 \mathrm{~mm}$ ) are well within those referenced for the Iberian Peninsula, but the maximum valve length of $C$. grubei $(15.1 \mathrm{~mm})$ is about $25 \%$ higher than that reported for this species. The morphometric relation studied for T. c. mauritanicus (standard length / carapace length) show sexual dimorphism, while that studied for C. grubei (valve height / valve length) show no difference between sexes. For both species, modal analysis of length frequency distributions suggests the presence of only one cohort. Concerning the sex ratio and although there seems to be a 1:1 ratio for both T. c. mauritanicus and $C$. grubei, we have found that this ratio is variable among samples.
\end{abstract}

Keywords: Notostraca, Spinicaudata, temporary ponds, biological data.

\section{RESUMEN}

La falta de información sobre Notostraca y Spinicaudata en general, y en particular sobre estas taxa en Portugal, puede ser debida a que son típicas de lagunas e charcas temporales. Dado que la mayoría de estas especies aparecen solamente en este tipo de hábitats, altamente vulnerables a la acción humana, es clara la importancia del estudio de dichos sistemas con el fin de definir estrategias para su conservación. En Abril de 1996, Triops cancriformis mauritanicus - Branchiopoda, Notostraca - fue detectado en seis lagunas del area de Vila do Bispo, en dos de las cuales se encontró también Cyzicus grubei (Simon) Branchiopoda, Spinicaudata - una especie considerada endemica de la Península Ibérica. A pesar de haber sido previamente citadas como parte de la fauna portuguesa (en 1944 y 1951) no han sido registradas en el SW portugués sino recientemente (Machado et al., 1999), ni existen otras referencias recientes en Portugal. Las dimensiones de T. c. mauritanicus ( longitud standard máxima $=68.3 \mathrm{~mm}$ ) están dentro de las descritas para la Península Ibérica; sin embargo la longitud máxima de la valva en C. grubei $(15.1 \mathrm{~mm})$ es aproximadamente un $25 \%$ superior a la descrita para esta especie. La relación morfométrica estudiada en T. c. mauritanicus (longitud standard / longitud del caparazón) muestra dimorfismo sexual, mientras que la estudiada en C. grubei (altura de la valva / longitud de la valva) no muestra diferencias entre sexos. En ambas especies, el análisis modal de la frecuencia de longitudes apunta hacia la presencia de una sola cohorte. En cuanto a la ratio de sexos, y aunque parece ajustarse a 1:1 tanto para T. c. mauritanicus como para $\mathrm{C}$. grubei, se ha encontrado que dicha relación es variable entre muestreos.

Palabras clave: Notostraca, Spinicaudata, charcas temporales, dados biológicos.

Limnetica 16: 1-7 (1999)

(C) Asociación Española de Limnología, Madrid. Spain. ISSN: 0213-8409 
Machado et al.

\section{INTRODUCTION}

The lack of information on large (non-cladoceran) Branchiopoda, particularly in Portugal, may be due to the fact that they are species typical of temporary ponds. The duration and timing of the flooding period of these habitats are dependent on the rain regime, which may vary from year to year and, perhaps for this reason, such ponds have attracted little interest among the scientific community. However, as large branchiopods occur mostly in this kind of habitat, which is highly vulnerable to human action, the study of these systems is clearly necessary in order to permit the definition of strategies for conservation.

In addition, the importance of temporary ponds has been recognised by the Portuguese government as a subscriber of the Directive 92/43/CEE, where Temporary Mediterranean Ponds are classified as priority habitats. Therefore, the study of their fauna and flora is essential.

In April of 1996, an unusual rainy year following a long period of drought, Triops cancriformis mauritanicus (Notostraca) and Cyzicus grubei (Spinicaudata), were found in several lagoons in the Vila do Bispo area (Fig. 1). In spite of having been previously reported in the Portuguese fauna, (Carvalho, 1944; Vianna-Fernandes, 1951), they were never listed in the Southwest region until very recently (Machado et al., 1999) and there are no other recent records in Portugal of these taxa. T. c. mauritanicus is a subspecies confined to Northwest Africa, the Balearic Islands and the southern half of the Iberian Peninsula (Longhurst, 1955; Alonso, 1985); C. grubei is a species endemic to the Iberian Peninsula and the Balearic Islands (Alonso, 1996).

This paper presents the first biological study of T. c. mauritanicus and C. grubei in the SW end of Portugal.

\section{MATERIAL AND METHODS}

\section{Study area}

During spring 1996, several temporary ponds in the Vila do Bispo area were inspected (Reis et al., 1997) (Fig. 1). These ponds are located in the Southwest Vicentine plateau, in those zones where the superficial sandy layer which covers the littoral Southwest plateau has not been eroded by the wind. The climate is Mediterranean with a clear Atlantic influence, presenting arid summers, torrential rain periods in autumn-winter and a strong annual wind regime. Table 1 summarises environmental characteristics of

Table 1. Environmental characteristics of temporary ponds inhabited by Cyzicus grubei and/or Triops cancriformis mauritanicus. Pond code follows Alcazar (1998). Persistence (P) scale : 1 - Usually dry before April; 2 - Usually dry before summer; 3 - Usually dry before autumn. Classes of ground cover by vegetation (GCV): $a-$ poor cover; $b-$ dense cover with bare zones. $(\mathrm{COND}$. = Conductivity, as measured in 13/4/96). Características ambientales de las lagunas temporales habitadas por Cyzicus grubei y/o Triops cancriformis mauritanicus. El código de lagunas de acuerdo con Alcazar (1998). Escala de persistencia (P): 1 - Normalmente seca antes de Abril; 2 - Normalmente seca antes del verano; 3 - Normalmente seca antes del otoño. Clases de cobertura vegetal (GCV): a - cobertura pobre; $b$ - cobertura densa con zonas libres. (COND. = Condutividad, medida el 13/4/96).

\begin{tabular}{ccccccccc}
\hline Pond & $\begin{array}{c}\text { Maximum } \\
\text { Area } \\
\left(\mathbf{m}^{\mathbf{2}}\right)\end{array}$ & $\begin{array}{c}\text { Maximum } \\
\text { Depth } \\
(\mathbf{m})\end{array}$ & $\begin{array}{c}\text { Soil } \\
\text { Nature }\end{array}$ & $\begin{array}{c}\text { Mean Annual } \\
\text { Rainfall } \\
(\mathbf{m m})\end{array}$ & $\mathbf{P}$ & $\begin{array}{c}\text { Cond. } \\
(\mathbf{m h o s})\end{array}$ & $\begin{array}{c}\text { GCV } \\
\text { Altitude } \\
(\mathbf{m} \text { a s } \mathbf{l})\end{array}$ \\
\hline G3 & 7300 & $>1$ & Sandy-clayish & 400 & 3 & 300 & $\mathrm{~b}$ & 75 \\
G12 & 72000 & $>1$ & Sandy-clayish & 480 & 2 & 290 & $\mathrm{~b}$ & 135 \\
G16 & 3500 & $>1$ & Sandy-clayish & 480 & 3 & - & $\mathrm{b}$ & 135 \\
G35 & 1900 & 0.7 & Sandy-clayish & 480 & 2 & 300 & $\mathrm{~b}$ & 135 \\
G37 & 13300 & 0.7 & Sandy-clayish & 400 & 1 & 1500 & $\mathrm{a}$ & 60 \\
Budens & 45000 & $>1$ & Sandy & 480 & 3 & 300 & $\mathrm{~b}$ & 140 \\
\hline
\end{tabular}




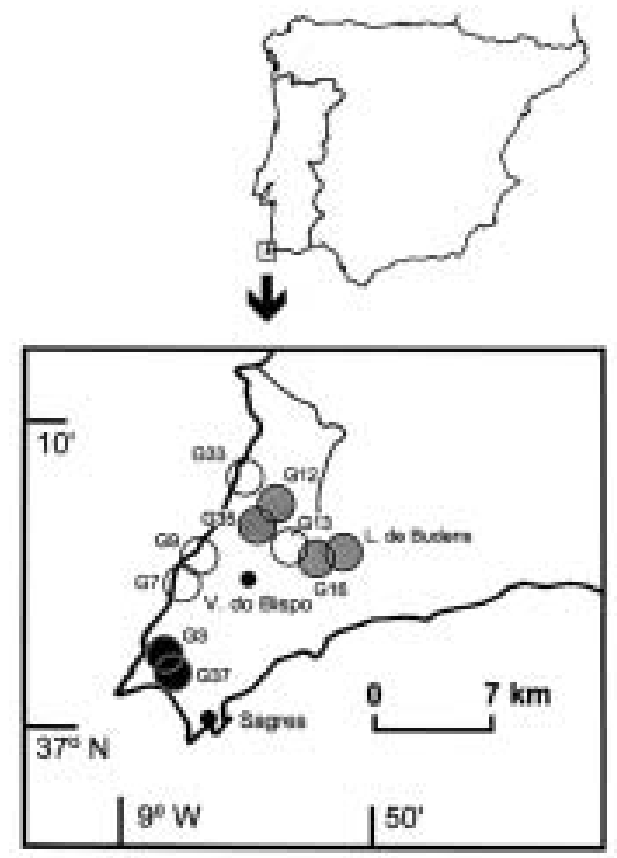

Figure 1. Inspected temporary ponds in the Vila do Bispo area; black circles symbolise ponds inhabited by Triops cancriformis mauritanicus and Cyzicus grubei; grey circles, ponds inhabited by T. c. mauritanicus; and blank circles, ponds where neither of these taxa were found. Pond code follows Alcazar (1998). Lagunas temporales inspeccionadas en el area de Vila do Bispo; los círculos negros representan lagunas habitadas por Triops cancriformis mauritanicus y Cyzicus grubei; los círculos grises, lagunas habitadas por T. mauritanicus; los círculos blancos, lagunas donde ninguno de estos taxa ha sido encontrado. El código de lagunas de acuerdo con Alcazar (1998).

Table 2. Triops cancriformis mauritanicus and Cyzicus grubei 1996 sampling. Pond code follows Alcazar (1998). (Dry ind. = Individuals collected after pond drying). Triops cancriformis mauritanicus y Cyzicus grubei - Muestreo 1996. El código de lagunas de acuerdo con Alcazar (1998). (Dry ind. = Individuos recogidos después del secado de la laguna).

\begin{tabular}{ccccc}
\hline $\begin{array}{c}\text { Sampled } \\
\text { Ponds }\end{array}$ & $\begin{array}{c}\text { T. cancriformis } \\
\text { mauritanicus }\end{array}$ & Cyzicus grubei \\
& Date & Number & Date & Number \\
\hline G12 & $13 / 4$ & 2 & & \\
G35 & $13 / 4$ & 5 & & \\
Budens & $13 / 4$ & 5 & & \\
G3 & $13 / 4$ & 6 & $13 / 4$ & 5 \\
G37 & $30 / 3$ & 76 & $30 / 3$ & 39 \\
G37 & $13 / 4$ & 50 & $13 / 4$ & 95 \\
G37 & & & Dry ind. & 104 \\
\hline
\end{tabular}

those ponds where Triops cancriformis mauritanicus and/or Cyzicus grubei were found.

\section{Sampling}

Punctual samples of Triops cancriformis mauritanicus and Cyzicus grubei were taken from inspected ponds in different occasions (Table 2). The samples were collected using a $6 \mathrm{~mm}^{2}$ mesh hand net. Samples were preserved in $70 \%$ ethilic alcohol, for posterior analysis. Animals collected in April from pond G37 were kept alive in an aquarium. In December 11, pond G37 was still dry and a sample of dried specimens of $C$. grubei was taken at its lowest point, were they had accumulated. This indicates that most of them must have died at the time the pond dried completely. The exact time of this occurrence could not be determined.

The recorded biological data were: standard length (carapace anterior tip to telson posterior tip), carapace length (measured along the median ridge) and sex, for T. c. mauritanicus; and valve length, valve height and sex, for $C$. grubei.

The animals kept in aquarium were processed only after their natural death, which occurred between April and June 1996. The dry specimens of $C$. grubei were rehydrated before being observed and measured.

\section{Data analysis}

For Triops cancriformis mauritanicus as for Cyzicus grubei, the corresponding population densities have allowed studies on biometric relationships and population structure only in pond G37. The population structure was only determined based on the sample of 30/3/96 since this is the only true punctual sample from this pond.

Comparison of medium length values was performed through $t$ Student tests. Regression lines were compared, using the Snedcor and Cochrane (1980) method. Length frequency distributions were built using the 3 class moving average method (Castro \& Gancho, 1996). The cohort 
analysis was performed by applying the Harding and Cassie method through the ANAMOD program (Nogueira, 1992).

\section{RESULTS AND DISCUSSION}

\section{Triops cancriformis mauritanicus}

The relationship between carapace length and standard length is shown in figure 2 for males and females. When compared, these two regression lines were found to differ significantly only in the intersept $(p<0.001)$. This result shows that, with-

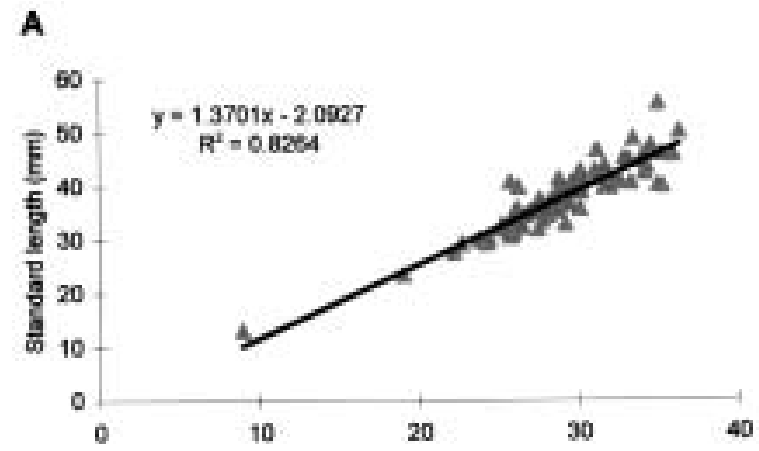

B

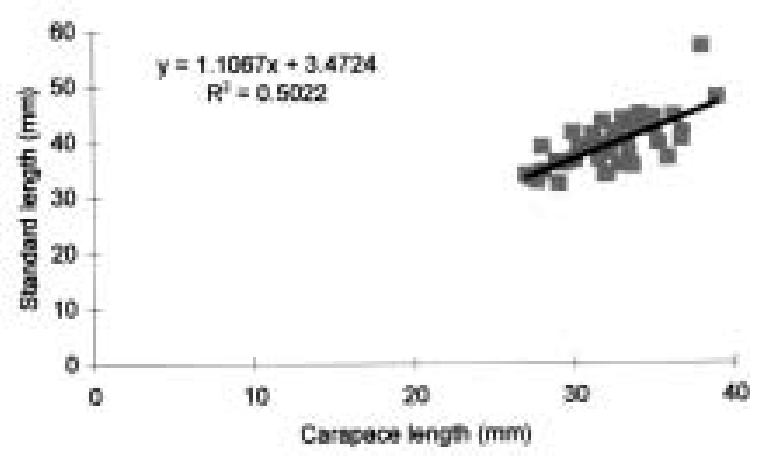

Figure 2. Triops cancriformis mauritanicus from pond G37: regression lines of standard length on carapace length for males (A) and females (B). Triops cancriformis mauritanicus de la laguna G37: rectas de regresión entre longitud standard y longitud del caparazón en machos $(A)$ y hembras $(B)$. in the considered length range, females have a bigger carapace than males (Fig. 2), a fact that had already been noted by other authors (Longhurst, 1955).

Table 3. Triops cancriformis mauritanicus - biometric value ranges for males and females. ( $\mathrm{N}=$ total number of individuals - number of individuals which could not be measured and/or sexed). Triops cancriformis mauritanicus - Rangos de valores biométricos en machos y hembras. $\left(N=n^{o}\right.$ total de individuos $-n^{o}$ de individuos no medibles y/o no atribuibles a un sexo).

\begin{tabular}{lcc}
\hline Parameter & $\begin{array}{c}\text { Males } \\
(\mathrm{N}=79)\end{array}$ & $\begin{array}{c}\text { Females } \\
(\mathrm{N}=54)\end{array}$ \\
\hline $\begin{array}{l}\text { Standard } \\
\text { length }(\mathrm{mm})\end{array}$ & $23.35-56.75$ & $32.26-68.27$ \\
$\begin{array}{l}\text { Carapace } \\
\text { length }(\mathrm{mm})\end{array}$ & $19.05-45.55$ & $27.01-56.31$ \\
\hline
\end{tabular}

The maximum recorded standard length (Table 3) is well within that reported for the Iberian Peninsula - 70mm (Alonso, 1996).

The results of the study on population structure of T. c. mauritanicus in pond G37 are presented in figure 3 . The medium value of the female carapace length distribution $(32.2 \mathrm{~mm})$ proved to be significantly higher $(\mathrm{p}<0.001)$ than the corresponding value for males $(27.8 \mathrm{~mm})$. Concerning the male distribution, a modal analysis was successfully attempted. The unimodal theoretical distribution was not significantly different $(p>0.05)$ from the observed carapace length frequency distribution and, in fact, a very good adjustment was obtained (fig. 3). This seems to indicate that only one cohort was present in the population. However, subsequent studies by the same authors (work in progress) indicate the possibility of the existence of subsequent, less important generations. This was also noted by Alonso (1996).

The sex ratios recorded in the sampled ponds are shown in Table 4. In two out of three samples, the values are close to the unity. Triops cancriformis is a species that shows a variation in sex ratio with the latitude (Nourisson \& Thiéry, 



Figure 3. Triops cancriformis mauritanicus from pond G37 (30/3/96): carapace length frequency distribution for males and females; modal analysis for male distribution. The arrow indicates the medium point of the theoretical distribution. Triops cancriformis mauritanicus de la laguna G37 (30/3/96): distribución de frecuencias de la longitud del caparazón en machos y hembras; análisis modal de la distribución en machos. La flecha indica el punto medio de la distribución teórica.

Table 4. Triops cancriformis mauritanicus - percentage of males and females in different samples. $(\mathrm{N}=$ total number of individuals number of individuals which could not be sexed). Triops cancriformis mauritanicus - porcentaje de machos y hembras en diferentes muestreos. $\left(N=n^{o}\right.$ total de individuos $-n^{o}$ de individuos no atribuibles a un sexo).

\begin{tabular}{lccc}
\hline Sample & N & \% Males & \% Females \\
\hline G37 30/3/96 & 76 & 71.1 & 28.9 \\
G37 13/4/96 & 42 & 45.2 & 54.8 \\
Other ponds & 17 & 47.1 & 52.9 \\
13/4/96 & & & \\
\hline
\end{tabular}

1988). Above $50^{\circ} \mathrm{N}$ the populations are usually composed strictly by females; between $45^{\circ} \mathrm{N}$ and $50^{\circ} \mathrm{N}$ there is a low percentage of males; below $45^{\circ} \mathrm{N}$ the sex ratio is $1: 1$. According to Longhurst (1955) the subspecies mauritanicus is bisexual.

However, Thiéry (1978) noticed that, besides that related to the latitude, there is a great variabili- ty in the sex ratio of Notostraca, which may be due to a differential microdistribution of sexes in the habitat and different male and female life span.

Hence care must be taken when discussing punctual sample results. The deviation of the value recorded for the first sample taken from pond $\mathrm{G} 37$ from the expected 1:1 ratio, could be due to a differential mortality between sexes related to a greater tolerance of males to adverse environmental conditions, since branchiopods were collected from an isolated pool which was about to dry. In relation to this, Thiéry (1987) has observed that males of the Morrocan branchiopod species are often dominant at the end of the hydrologic cycle.

Table 5. Cyzicus grubei - biometric value ranges for males and females. ( $\mathrm{N}=$ total number of individuals - number of individuals which could not be sexed). Cyzicus grubei - Rangos de valores biométricos en machos y hembras. $\left(N=n^{o}\right.$ total de individuos $-n^{o}$ de individuos no atribuibles a un sexo).

\begin{tabular}{lcc}
\hline Parameter & $\begin{array}{c}\text { Males } \\
(\mathrm{N}=128)\end{array}$ & $\begin{array}{c}\text { Females } \\
(\mathrm{N}=60)\end{array}$ \\
\hline Valve length $(\mathrm{mm})$ & $9.76-15.12$ & $\begin{array}{c}10.90-13.76 \\
7.28-9.31\end{array}$ \\
Valve height $(\mathrm{mm})$ & $6.90-10.32$ & \\
\hline
\end{tabular}

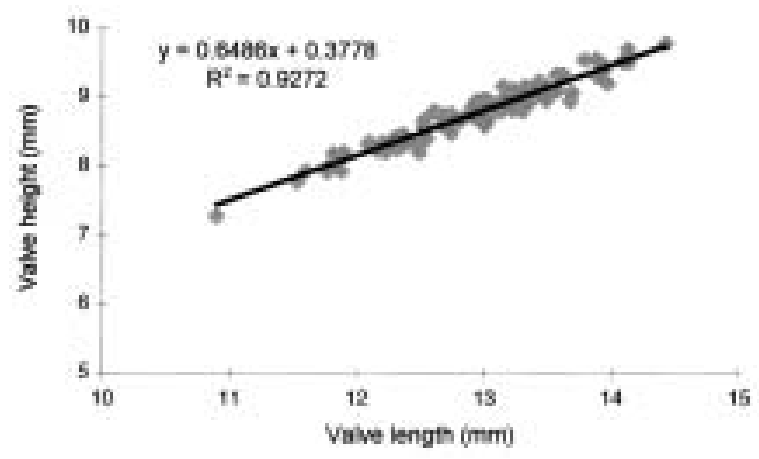

Figure 4. Cyzicus grubei from pond G37: regression line of valve height on valve length. Cyzicus grubei de la laguna G37: recta de regresión entre altura y longitud de la valva. 


\section{Cyzicus grubei}

The morphometric relationships between valve height and valve length for males and females proved to be non significantly different ( $\mathrm{p}>0.05)$; therefore data from both sexes were pooled (Fig. 4). The resulting regression line characterises the population of $C$. grubei from pond G37 under the prevailing environmental conditions at the 1995/96 flooding period.

The maximum valve length (Table 5) was about $25 \%$ higher than that previously cited -12 mm (Alonso, 1996).

The results of the study on population structure of $C$. grubei from pond G37 are presented in figure 5 . The medium value of male valve length distribution $(12.9 \mathrm{~mm})$ proved to be significantly higher $(\mathrm{p}<0.001)$ than that relative to the females $(12.2 \mathrm{~mm})$. Concerning the male distribution, a

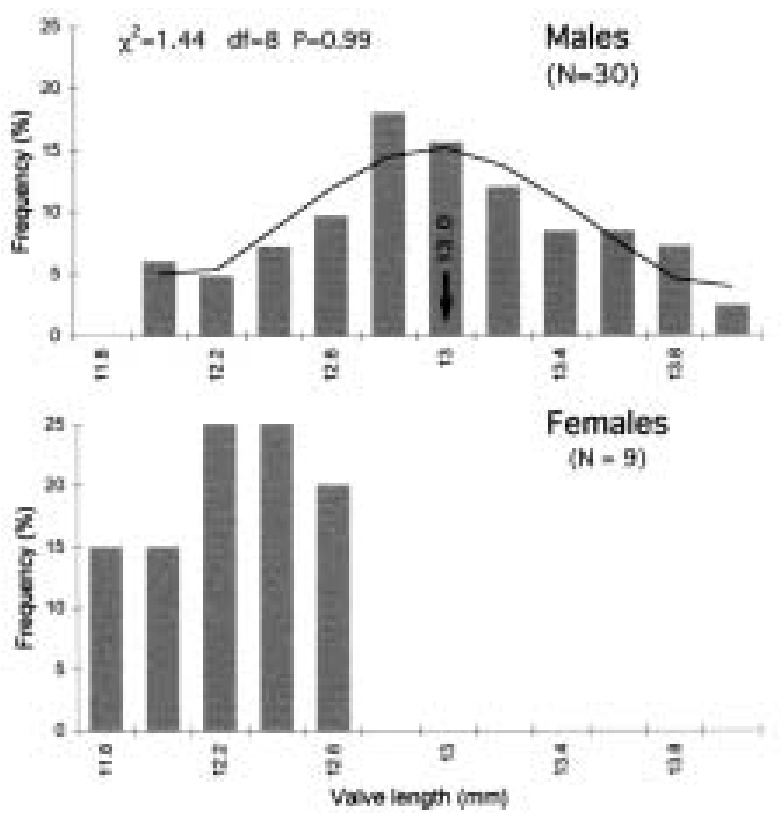

Figure 5. Cyzicus grubei from pond G37 (30/3/96): valve length frequency distribution for males and females; modal analysis for male distribution. The arrow indicates the medium point of the theoretical distribution. Cyzicus grubei de la laguna G37 (30/3/96): distribución de frecuencias de la longitud de la valva en machos y hembras; análisis modal de la distribución en machos. La flecha indica el punto medio de la distribución teórica.
Table 6. Cyzicus grubei - percentage of males and females in different samples. ( $\mathrm{N}=$ total number of individuals - number individuals which could not be sexed). Cyzicus grubei - porcentaje de machos $y$ hembras en diferentes muestreos. $\left(N=n^{o}\right.$ total de individuos $-n^{o}$ de individuos no atribuibles a un sexo).

\begin{tabular}{rrrr}
\hline \multicolumn{1}{c}{ Sample } & N & \% Males & \% Females \\
\hline G37 30/3/96 & 39 & 76.9 & 23.1 \\
G37 13/4/96 & 63 & 77.8 & 22.2 \\
G3 13/4/96 & 4 & 75 & 25 \\
G37 Dry ind. & 86 & 57 & 43 \\
\hline
\end{tabular}

modal analysis was performed. The resulting unimodal theoretical distribution was not significantly different $(p>0.05)$ from the observed valve length frequency distribution (Fig. 5). This indicates the existence of a single cohort for the duration of the flooding period. Such assumption could be confirmed by subsequent observations.

The sex ratios recorded were close to $4: 1$ in all samples taken from living populations, but not in that from the dry individuals (Table 6).

As Sassaman (1995) has pointed out, sex ratios based on field samples from natural populations should be viewed with caution, as males and females may display a differential microdistribution in the habitat due to a differential behaviour, ecological preferences or microhabitat uses. Furthermore, the two sexes may differ in survivorship.

In Cyzicidae, sex ratio is characterised by an equality between males and females (Sassaman, 1995). So the ratio observed in our samples suggests the existence of a different distribution pattern of the two sexes in these habitats, which disappear as far as the water body diminishes, and the animals are forced to concentrate in small pools, just before dying desiccated.

This first approach to the study of Branchiopoda populations in SW Portugal provides much needed background information for future studies, aiming to increase our knowledge of the biology and ecology of these species, and thus contributing to the establishment of suitable measures for the correct management of temporary ponds. 
Further work is urgently required and essential for the development of strategies for the conservation and management of these endangered and fragile habitats.

\section{ACKNOWLEDGEMENTS}

We would like to thank the Parque Natural do Sudoeste Alentejano e Costa Vicentina for their financial support. Thanks are also due to Pedro Beja, Rita Alcazar, Luis Palma and Carlos Noivo for providing information related to some ponds; Margarida Castro for assistance in data analysis; Jeffrey Wallace and Leonor Cancela for the English revision of the manuscript; and Juan Fuentes for the translation of the abstract, figure captions and table headings into Spanish.

\section{REFERENCES}

ALCAZAR, R. 1998. Impactos da agricultura nas lagoas temporárias do Parque Natural do Sudoeste Alentejano e Costa Vicentina. Estágio de licenciatura. Faculdade de Ciências da Universidade de Lisboa, 47 pp.

ALONSO, M. 1985. A survey of the Spanish Euphyllopoda. Misc. Zool., 9: 179-208.

ALONSO, M. 1996. Crustacea Branchiopoda. Fauna Ibérica, 7: 1-486. Museo Nacional de Ciencias Naturales, Consejo Superior de Investigaciones Científicas. Madrid.

CARVALHO, R. N. 1944. Catálogo da colecção de invertebrados de Portugal existentes no Museu Zoológico da Universidade de Coimbra. Crustacea. Mem. Est. Mus. Zool. Univ. Coimbra, 160: 1-15.

CASTRO, M. \& P. GANCHO 1996. Signal and noise in length sequency analysis. Colloquium Crustacea Decapoda Mediterranea, Florence, Abstracts volume: 23-24.

LONGHURST, A. R. 1955. A review of the Notostraca. Bull. Brit. Mus. Nat. Hist. Zool., 3: 1-57.

MACHADO, M., M. CRISTO \& L. CANCELA DA FONSECA 1999. Non-Cladoceran Branchiopod Crustaceans from Southwest Portugal. I. Occurrence note. Crustaceana, 72 (6): 591-602.

NOGUEIRA, A. J. 1992. Anamod - Extracção dos componentes modais de distribuições de frequên- cias de variáveis biométricas. Trabalho de síntese, Provas de Aptidão Pedagógica e Capacidade Científica. Univ. Coimbra, 67 pp.

NOURISSON, M. \& A. THIÉRY 1988. Introduction pratique à la systématique des organismes des eaux continentales françaises. 9. Crustacés Branchiopodes (Anostracés, Notostracés, Conchostracés). Bull. mens. Soc. Linn. Lyon, 57: 75-95.

REIS, J., M. MACHADO, M. CRISTO \& L. CANCELA DA FONSECA 1997. Ocorrência de Triops cancriformis mauritanicus (Ghigi) e de Cyzicus grubei (Simon) (Crustacea, Branchiopoda) em lagoas temporárias do Sudoeste de Portugal. Relat. Interno. Parque Natural do Sudoeste Alentejano e Costa Vicentina. Odemira. 43 pp.

SASSAMAN, C. 1995. Sex determination and evolution of unisexuality in the Conchostraca. Hydrobiologia, 298: 45-65.

SNEDCOR, G. W. \& W. COCHRANE. 1980. Statistical Methods. $7^{\text {th }}$ ed. Ames.:The Iowa State University Press.

THIÉRY, A. 1978. Étude des communautés d'invertébrés aquatiques dans différents biotopes des marais du Plan-de-Bourg (Bouches-du-Rhône, France). These $3^{\mathrm{e}}$ cycle, Université d'AixMarseille III, 171 pp.

THIÉRY, A. 1987. Les Crustacés Branchiopodes Anostraca, Notostraca et Conchostraca des milieux limniques temporaires (Dayas) au Maroc. Taxonomie, biogéographie, écologie. $\mathrm{Ph}$. D. Thesis, Université d'Aix-Marseille III, 405 pp.

VIANNA-FERNANDES, A. M. 1951. Contribuições para o estudo dos Filópodes portugueses. I. Primeiras espécies encontradas em Portugal. Arq. Mus. Bocage, 22: 75-85. 